\title{
Precise aftershock distribution and crustal structure in and around the northern focal area of the 2008 Iwate-Miyagi Nairiku Earthquake
}

\author{
Eiji Kurashimo ${ }^{1}$, Hiroshi Sato ${ }^{1}$, Susumu Abe $^{2}$, Takaya Iwasaki ${ }^{1}$, Takashi Iidaka ${ }^{1}$, \\ Naoko Kato $^{1}$, Shin Koshiya ${ }^{3}$, Taku Kawanaka ${ }^{2}$, and Naoshi Hirata ${ }^{1}$ \\ ${ }^{1}$ Earthquake Research Institute, the University of Tokyo, 1-1-1 Yayoi, Bunkyo-ku, Tokyo 113-0032, Japan \\ ${ }^{2}$ JGI, Inc., 1-5-21 Otsuka, Bunkyo-ku, Tokyo 112-0012, Japan \\ ${ }^{3}$ Iwate University, 4-3-5 Ueda, Morioka, Iwate 020-8551, Japan
}

(Received November 12, 2010; Revised March 9, 2011; Accepted April 7, 2011; Online published December 29, 2011)

\begin{abstract}
The 2008 Iwate-Miyagi Nairiku Earthquake $\left(M_{\mathrm{j}} 7.2\right)$ occurred on June 14, 2008, at the eastern flank of the Ou backbone range, in the central part of northern Honshu, Japan. In the northern part of the focal area, seismic reflection/refraction experiments conducted in 2006 and 2007 revealed a series of west-dipping faults. To investigate the relation between these faults and aftershocks, we conducted a high-density seismic array observation across the northern focal area. The arrival times of earthquakes were used in a joint inversion for earthquake locations and velocity structure. The $V_{p}$ structure shows tilted blocks and the block boundaries coincide with the revealed west-dipping faults. These faults were interpreted to have formed during the Miocene extension. The aftershock distribution shows a concentration on a plane dipping westward approximately $40^{\circ}$ beneath the eastern margin of the Ou backbone range. The zone of aftershock concentration can be correlated to the known range-bounding fault inferred from seismic profiling and does not coincide with the known active reverse fault (Dedana fault). These results indicate the significance of the potential source fault located along the boundary of the Ou backbone range.
\end{abstract}

Key words: The 2008 Iwate-Miyagi Nairiku Earthquake, high-density seismic array observation, seismic tomography, aftershock distribution, fault reactivation.

\section{Introduction}

A large shallow earthquake occurred in the central part of northern Honshu (Iwate Prefecture), Japan, at 8:43 AM Japan standard time (JST, UT +9 h) on June 14, 2008, with a Japan Meteorological Agency (JMA) magnitude $\left(M_{\mathrm{j}}\right)$ of 7.2 (Fig. 1). This earthquake, named the Iwate-Miyagi Nairiku Earthquake in 2008 by JMA, caused an uplift of the Ou backbone range (e.g., Takada et al., 2009). According to the JMA (2008), this earthquake had a reverse faulting type focal mechanism with a compression axis on the strike of WNW-ESE. The focal area of this earthquake was mainly located in the Ou backbone range parallel to the range extension (Okada et al., 2008). On the basis of topographical features, the focal area is divided into the $\mathrm{Ou}$ backbone range and the Kitakami lowland parallel to the arc. The Kitakami lowland is located at the eastern edge of the Miocene northern Honshu rift system (Sato, 1994) and marked by a series of west-dipping Miocene normal faults (Kato et al., 2006; Abe et al., 2008). The Dedana fault (Active Fault Research Group, 1991), one of the Miocene normal faults, has been reactivated as a reverse fault since the Pliocene (Sato, 1994; Kato et al., 2006). Seismic reflection/refraction experiments were conducted across the

Copyright (c) The Society of Geomagnetism and Earth, Planetary and Space Sciences (SGEPSS); The Seismological Society of Japan; The Volcanological Society of Japan; The Geodetic Society of Japan; The Japanese Society for Planetary Sciences; TERRAPUB.

doi:10.5047/eps.2011.04.001
Dedana fault in 2006 and 2007 (e.g., Abe et al., 2008). The deeper extension of the west-dipping listric faults was well demonstrated on the seismic reflection section (Abe et al., 2008). To reveal the relation between an active fault system and aftershock distribution, it is important to study the longterm behavior of active faults. The Japanese islands, including the focal area of the 2008 Iwate-Miyagi Nairiku Earthquake and its surrounding region, are covered with dense arrays of permanent seismic stations. Nonetheless, an average distance of approximately $20 \mathrm{~km}$ between these seismic stations does not enable the relation to be resolved between the fault geometry, revealed by seismic reflection experiments, and aftershock distribution. The geological structure of the northern part of the focal area is adequately shown by seismic reflection profiles (Kato et al., 2006; Abe et al., 2008; Saito et al., 2008). Therefore, we have conducted a highdensity, 40-km-long, seismic array observation across the northern focal area to investigate the aftershock distribution and crustal structure. In this paper, we present a precise aftershock distribution and seismic velocity structure in and around the northern focal area of the 2008 Iwate-Miyagi Nairiku Earthquake derived from high-density aftershock observations and we discuss the relation between the source fault and the known geological structure.

\section{Seismic Array Observation}

We conducted a high-density, 40-km-long seismic array observation across the northern focal area of the 2008 


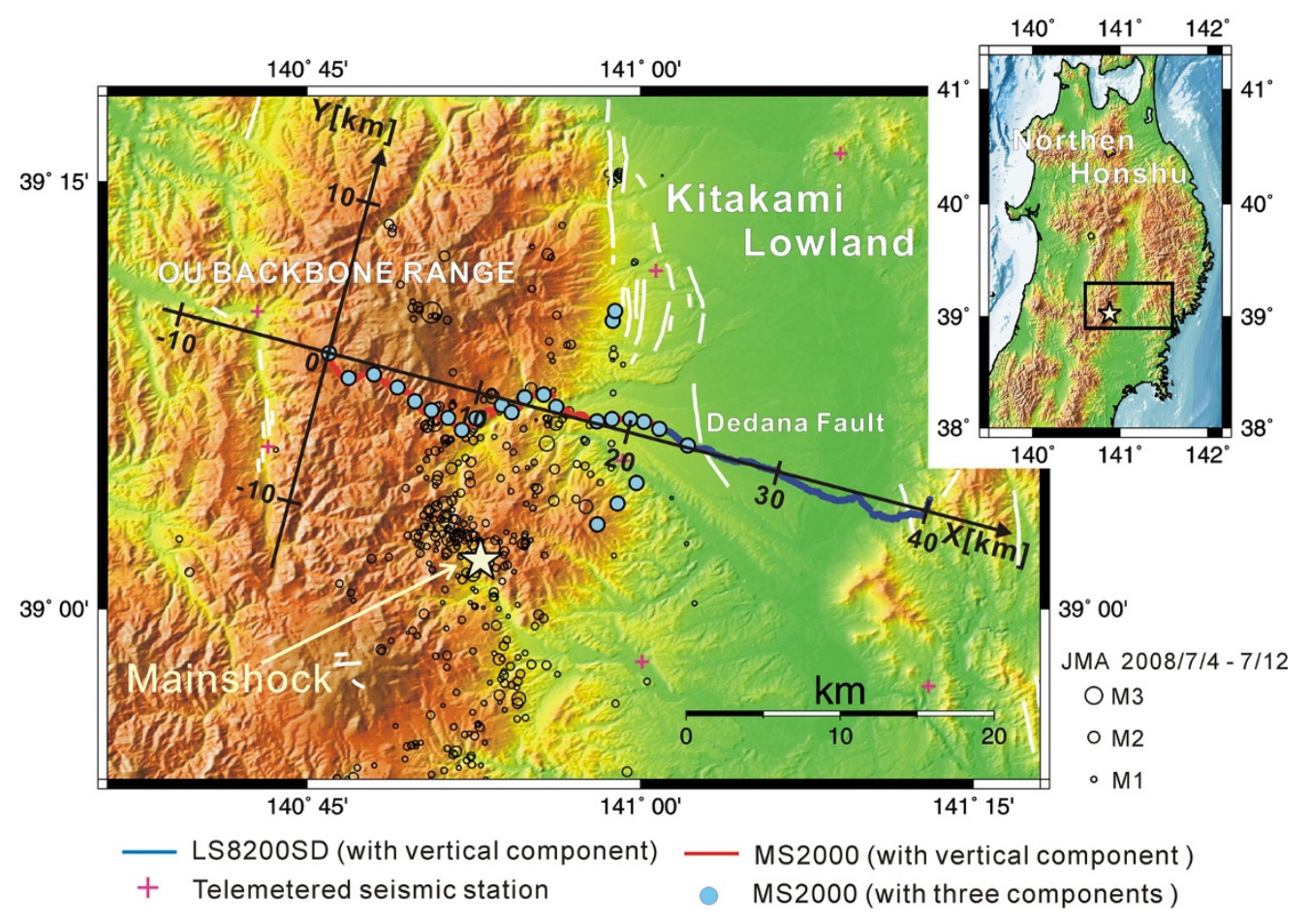

Fig. 1. Location map of the 2008 Iwate-Miyagi Nairiku Earthquake. The study area is indicated by a solid square (inset map). Red and blue lines indicate the seismic array of vertical-component seismometers. Blue circles indicate seismic stations with three-component seismometers. Red crosses indicate telemetered seismic stations used in the present study. Aftershock hypocenters determined by the JMA (2008/7/4-7/12) are shown as open circles scaled to earthquake magnitude. The star indicates the mainshock. The $X-Y$ coordinate system used in the 3-D inversion is also shown.

Iwate-Miyagi Nairiku Earthquake over an eight-day period beginning at 18:00 on July 4 (Kurashimo et al., 2011 in press). 277 seismic stations, approximately $150 \mathrm{~m}$ apart, were installed on a survey line in the east-west direction (Fig. 1). 257 stations had a vertical-component velocity seismometer with a natural frequency of $4.5 \mathrm{~Hz}$ and the remaining 20 stations had three-component velocity seismometers with a natural frequency of $2.0 \mathrm{~Hz}$ or three-component accelerometers. Three-component seismic stations, approximately $1 \mathrm{~km}$ apart, were principally installed at the western part of the survey line. To improve the accuracy of hypocenter locations, we additionally deployed 5 three-component seismic stations around the survey line. We used two types of off-line recorders: one was LS8200SD (Kurashimo et al., 2006), and the other was a JGI's MS2000. Both off-line recorders include a global positioning system (GPS) receiver to maintain the accuracy of the internal clock. Seismic waveform data were continuously recorded at sampling rates of $125 \mathrm{~Hz}$ (LS8200SD) and $250 \mathrm{~Hz}$ (MS2000), respectively.

\section{Data}

We combined our seismic array data with telemetered seismic data obtained by the Earthquake Research Institute, the University of Tokyo, the National Research Institute for Earth Science and Disaster Prevention, and the JMA. We used seven telemetered seismic stations in the present study (Fig. 1). The continuously recorded data were divided into event files, starting from an origin time determined by the JMA. During the seismic array observation, the JMA located 353 earthquakes in a latitude range of $38.9-39.3^{\circ} \mathrm{N}$ and a longitude range of $140.6-141.3^{\circ} \mathrm{E}$ (Fig. 1). We selected 135 earthquakes occurring within $7 \mathrm{~km}$ distance from the center of the seismic array and having high signal-tonoise ratios. We picked $P$-wave, and $S$-wave, arrivals of 135 local earthquake events at 289 seismic stations. 34,027 $P$-wave and 2,860 $S$-wave arrival times were obtained and used in an inversion analysis.

\section{Travel Time Inversion}

To investigate the aftershock distribution and the crustal structure, a tomography code simul2000 (Thurber and Eberhart-Phillips, 1999) was applied to the $P$-wave and $S$ wave arrival time data obtained from 135 local earthquakes. This code simultaneously solves for earthquake locations and a three-dimensional (3-D) velocity structure using $P$ arrival times and $S$-minus- $P$ times employing an iterative damped least-squares method. In simul2000, the $V_{p}$ value and the $V_{p} / V_{s}$ ratio are estimated at the nodes of a 3-D grid. We used an $x-y$ coordinate system with the $x$-axis pointing $\mathrm{N} 104^{\circ} \mathrm{E}$ and the $y$-axis pointing $\mathrm{N} 14^{\circ} \mathrm{E}$ (Fig. 1). Grid nodes for the tomography analyses are located at $-300,-10,0$, $2,4,6,8,10,12,14,16,18,20,22,24,26,28,30,32$, $34,36,38,40,50$, and $300 \mathrm{~km}$ on the $x$-axis; $-300,-20$, $-10,-5,0,5,10,20$, and $300 \mathrm{~km}$ on the $y$-axis; and -40 , $-1,0,1,2,3,4,5,6,7,8,9,10,11,12,15,20,25,30$, and $40 \mathrm{~km}$ on the $z$-axis. The solution of an inverse problem of 3-D local earthquake tomography, and its reliability, strongly depend on the initial one-dimensional (1-D) velocity model (e.g., Kissling, 1988). The initial 1-D velocity model used in the present study (Fig. 2) was obtained by resampling the $1-\mathrm{D}$ velocity model calculated by the joint 


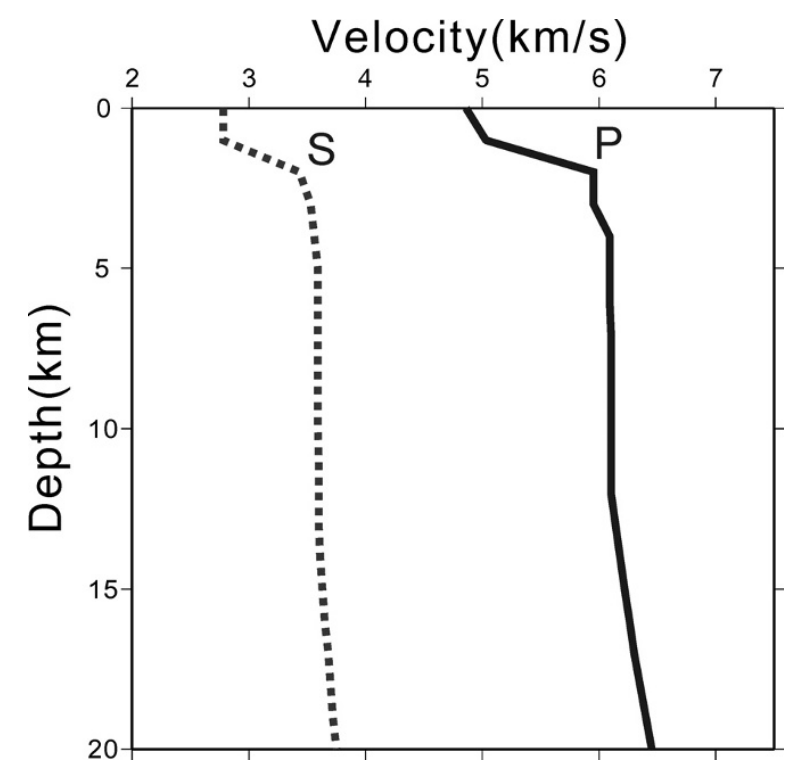

Fig. 2. Initial 1-D velocity model for 3-D inversion. The solid line denotes $P$-wave velocity, dashed line denotes $S$-wave velocity.

hypocenter determination (JHD) technique (Kissling et al., 1994) at the depths of the vertical grid nodes. The JHD technique simultaneously estimates the 1-D velocity model, earthquake locations, origin times, and station corrections. These estimates were used in this study as the initial model for the 3-D inversion. The final 3-D model achieved a $23 \%$ reduction in the root-mean-square (RMS) travel-time residuals in comparison with the initial 1-D velocity model, and had final overall RMS travel time residuals of $0.019 \mathrm{~s}$.

\section{Results and Discussion}

Figure 3(b) shows the vertical cross-section of the inverted $V_{p}$ structure along the $x$-axis $(Y=0 \mathrm{~km})$ with hypocenters relocated after the 3-D inversion. The prominent feature in Fig. 3(b) is a dipping block structure located in the horizontal range of $5-30 \mathrm{~km}$. The boundaries between each dipping block are characterized by a relatively low $V_{p}$. The hypocentral distribution of aftershocks shows a concentration on a plane dipping westward approximately $40^{\circ}$ beneath the eastern margin of the Ou backbone range. A large slip region (asperity) was inferred approximately $5 \mathrm{~km}$ south of the hypocenter of the main shock (Hikima $e t$ al., 2008; Yokota et al., 2009). A smaller asperity was also inferred approximately $7 \mathrm{~km}$ northeast of the hypocenter of the main shock at a depth of approximately $5 \mathrm{~km}$ (Yokota et al., 2009). Its location is shown in Fig. 3(b). A systematic difference between our aftershock distribution and the fault model assumed by Yokota et al. (2009) is due to an inadequate assumption of the fault location based on preliminary source inversion of geodetic and strong motion data. Considering this difference, it may be said that the low-activity region of the aftershocks corresponds to the asperity area of the main shock. Actually, our high-velocity region shows a good correspondence to the low-activity region of the aftershocks. Similar correspondences have been found in other earthquake areas such as the 2003 northern Miyagi Earthquake (Okada et al., 2007) and the 2004 Mid-Niigata Pre- fecture Earthquake (Kato et al., 2010). These results suggest that the high-velocity region with low aftershock activity beneath the eastern margin of the Ou backbone range corresponds to the region of asperity. On the basis of these studies, we can assume that structural heterogeneities in and around the fault plane may have controlled the rupture process of the 2008 Iwate-Miyagi Nairiku Earthquake.

The present $V_{p}$ model estimated from 3-D inversion can be compared with the surface geology (Kitamura, 1965; Ozawa et al., 1988; Takeuchi et al., 2005) and seismic reflection/refraction profile (Abe et al., 2008; Saito et al., 2008). We observed the aftershocks along the same seismic line as that of the 2006 and 2007 active source experiments. Positive station corrections are obtained at stations located in the horizontal range of $15-34 \mathrm{~km}$ for $P$ waves (max value: $0.4 \mathrm{~s}$ ), suggesting that low-velocity materials may exist at very shallow depths beneath those stations. Figure 3(b) also shows the low-velocity zone at a shallow depth in the western part of the survey line. On the basis of surface geology, we can suggest that the lowvelocity materials located at shallow depths represent Neogene sediments. The high-resolution refraction model of Saito et al. (2008) shows the dipping block structure, which is consistent with our $V_{p}$ structure. The seismic reflection profile (Abe et al., 2008) shows several westward-dipping Miocene normal faults, including the Dedana fault. The dipping block structures and the westward-dipping normal faults are evidence for the rift system formed during the Miocene (Kato et al., 2006). The Dedana fault is reactivated as a reverse fault. A deeper extension of the Dedana fault can be recognized on the seismic reflection profile (Abe $e t$ al., 2008). Comparison of the relocated aftershock distribution with the seismic reflection profile revealed that the deeper extension of the Dedana fault does not coincide with the planar distribution of the aftershocks (Figs. 3(b) and 4). Abe et al. (2008) also showed the westward-dipping fault at the eastern margin of the Ou backbone range. This fault is referred to as the range-bounding fault (RBF) in this study. Figures 3(b) and 4 show that the shallower extension of the planar aftershock distribution seems to meet the surface trace of the RBF estimated by Abe et al. (2008). On the basis of the heights of fluvial/marine terraces, Tajikara and Ikeda (2005) and Tajikara et al. (2009) pointed out that the blind faults may be located at the topographical boundary between a range and a basin, where the active faults have not been mapped. On the basis of GPS measurements, Ohta et al. (2008) revealed that no coseismic slip was estimated at the deeper extension of the Dedana fault. The upper edge of the coseismic fault deduced from a GPS observation was located several kilometers west of the surface trace of the Dedana fault (Ohta et al., 2008). These results indicate that the 2008 Iwate-Miyagi Nairiku Earthquake was generated by the reactivation of the normal fault, which is located at the eastern margin of the Ou backbone range.

The present study reveals the aftershock distribution and crustal structure in and around the northern focal area of the 2008 Iwate-Miyagi Nairiku Earthquake. Several westwarddipping faults are recognized on the seismic reflection profile. Our results can identify faults that actually generated the earthquake. We relocated 135 earthquakes listed in the 

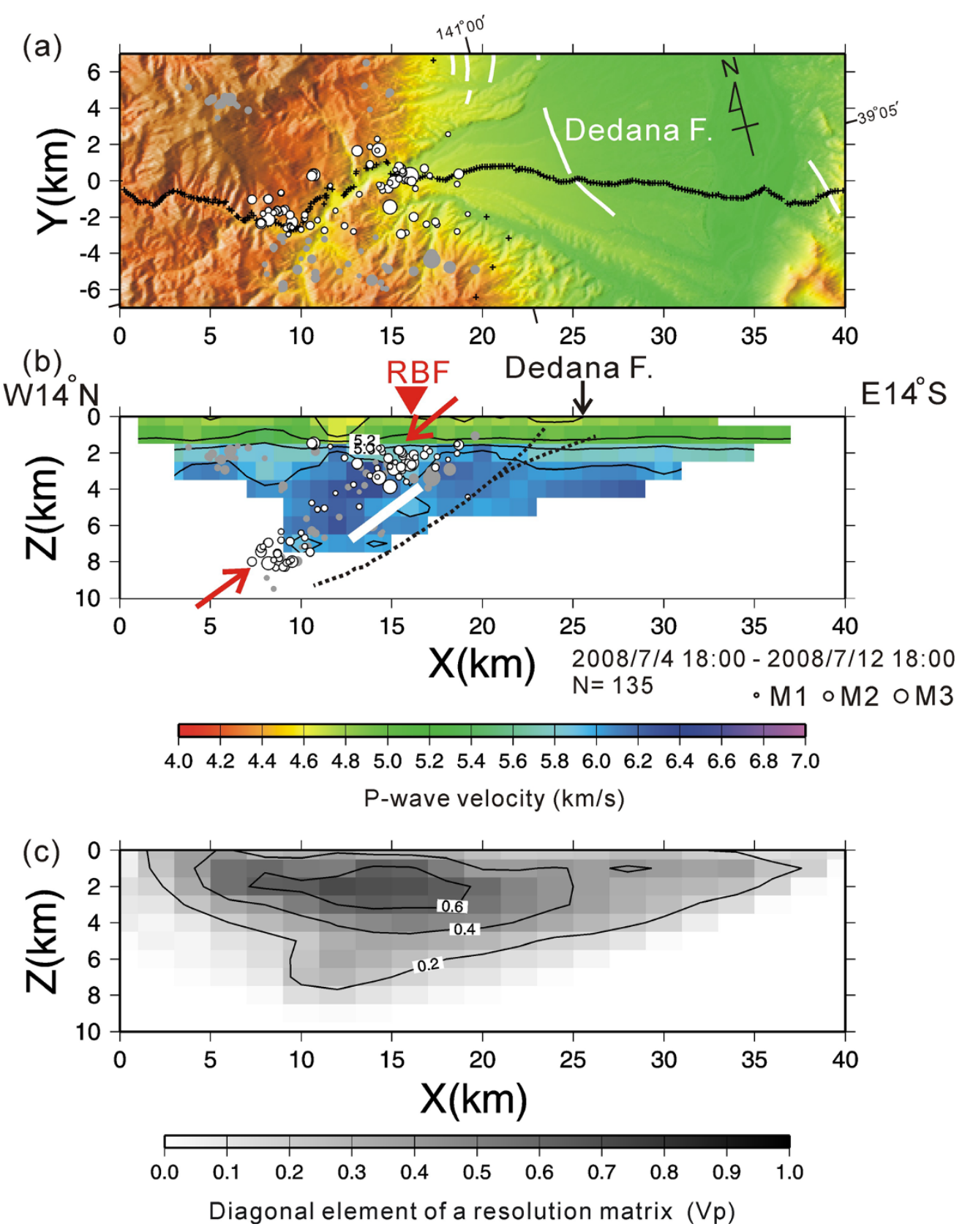

Fig. 3. (a) Epicenter distribution. White circles indicate hypocenters located within a 3-km-wide swathe centered on the profile $(Y=0 \mathrm{~km})$. Hypocenters distributed from 3 to $7 \mathrm{~km}$ from the profile $(Y=0 \mathrm{~km})$ are shown by gray circles. The circles are scaled to earthquake magnitudes. Crosses indicate seismic stations used in the present study. (b) Vertical cross-section of inverted $P$-wave velocity along $x$-axis $(Y=0 \mathrm{~km})$. Solid contour lines indicate $V_{p}$ in $\mathrm{km} / \mathrm{s}$. The contour interval is $0.4 \mathrm{~km} / \mathrm{s}$. $P$-wave velocity is also indicated by a color scale in km/s. Areas with a resolution value less than 0.2 are painted white. Thick dashed lines indicate the Dedana fault inferred from seismic reflection profiling (Abe et al., 2008). Red triangle indicates surface trace of the range-bounding fault estimated by Abe et al. (2008). The arrow labeled Dedana F. at the top of the figure denotes the location of the surface trace of the Dedana fault. The planar distribution of aftershocks is marked by red arrows. A white line shows an asperity area with a slip larger than $1.5 \mathrm{~m}$ within the 3-km-wide swathe centered on the profile (Yokota et al., 2009). (c) Diagonal elements of a resolution matrix $\left(V_{p}\right)$. Solid contour lines indicate the resolution value. The contour interval is 0.2 . The resolution value is also indicated by a gray scale.

unified JMA hypocenter catalog. The hypocenters determined by the JMA were approximately $5 \mathrm{~km}$ deeper than those relocated in this study (Fig. 5). This result indicates that the unified JMA hypocenter catalog lacks sufficient accuracy to consider the relation between an active fault system and aftershocks. A high-density aftershock observation is a powerful tool for identifying the seismic source fault and provides a new insight into the process of earthquake occurrence.

In spite of the clear topographical features, the RBF was not identified as an active fault. The Ou backbone range has been an arc parallel to a major uplifted zone since the Pliocene and is commonly bounded by active reverse faults. There is not much difference in the summit altitudes of the backbone range, whether bounded by active reverse faults or not, suggesting potential hidden active faults beneath the mountain flank. 


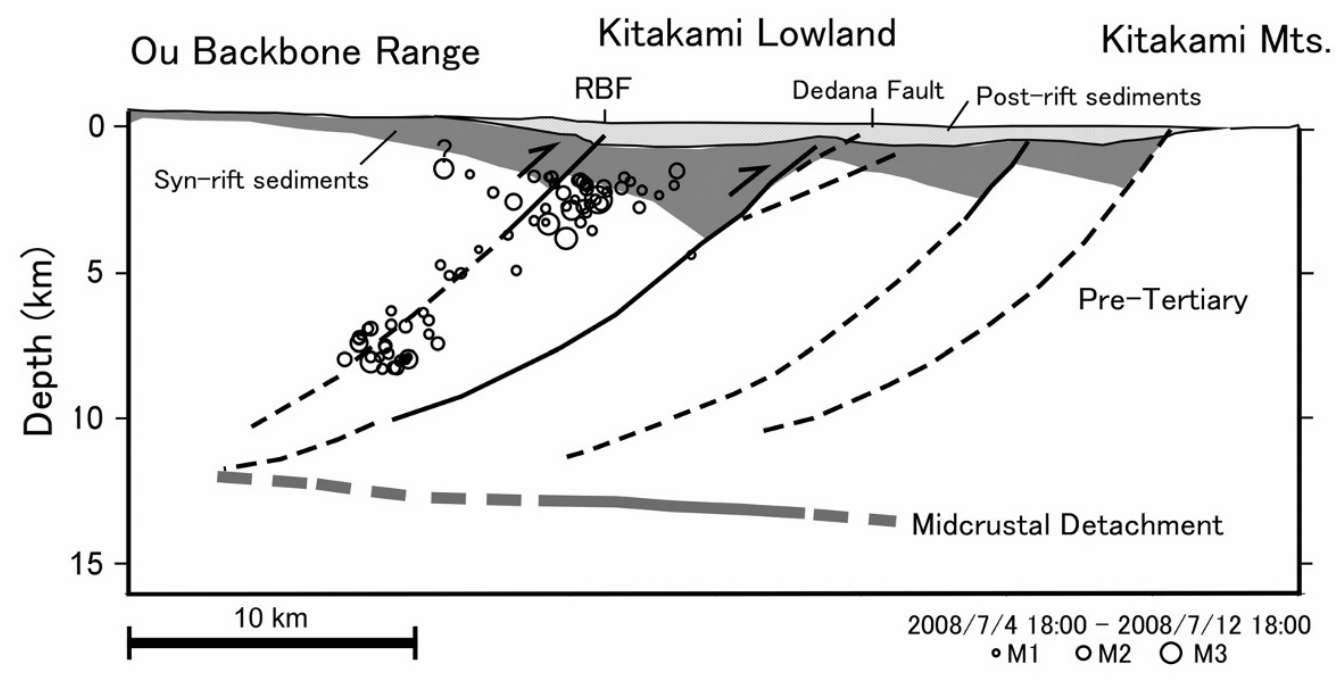

Fig. 4. Schematic diagram showing the relation between the aftershock distribution and the geological structure. Open circles indicate hypocenters located within a 3-km-wide swathe centered on the profile. The circles are scaled to the earthquake magnitude. The geological structure is after Abe et al. (2008).

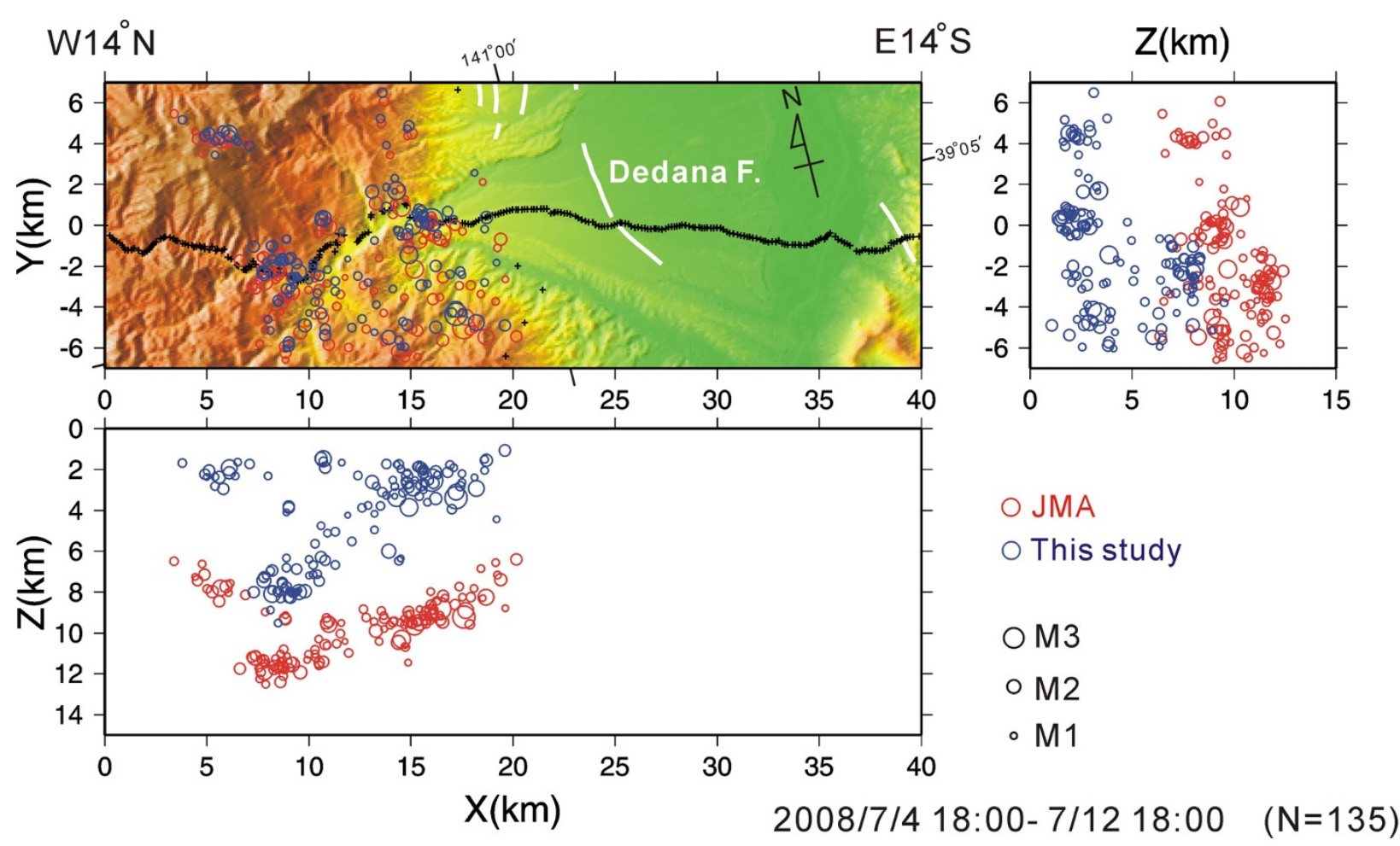

Fig. 5. Comparison between hypocenters determined by JMA during seismic array observation (red circles) and those determined in this study (blue circles). Crosses indicate seismic stations used in the present study.

\section{Conclusion}

We conducted a high-density seismic array observation across the northern focal area of the 2008 Iwate-Miyagi Nairiku Earthquake for eight days in order to investigate the aftershock distribution and the crustal structure. We obtained $P$-wave and $S$-wave arrival time data from 135 events and used 34,027 $P$-wave and 2,860 $S$-wave arrival times for the inversion analysis. The $P$-wave velocity structure shows westward-dipping block structures. The aftershock plane coincides with the deeper extension of the range-bounding fault estimated by Abe et al. (2008). GPS observation revealed that the upper edge of the coseismic fault was located several kilometers west of the surface trace of the Dedana fault, which is the southern part of the western marginal faults of the Kitakami lowland (Ohta et al., 2008). These results indicate that, in the northern part of the focal area, the 2008 Iwate-Miyagi Nairiku Earthquake occurred along the range-bounding fault, which is located at the eastern margin of the Ou backbone range. 
Acknowledgments. We are grateful to Mamoru Saka, Masaru Noda, Masato Serizawa, Fumiaki Sato, Fumiko Watahiki, Taro Mogi, and Rui Hanada, for data acquisition and wish to express our gratitude to Shinichi Sakai, Aitaro Kato, and Toshihiko Kanazawa for their help with preparations for the aftershock observation. We also wish to thank the National Research Institute for Earth Science and Disaster Prevention: the Japan Meteorological Agency: and the Earthquake Observation Center of the Earthquake Research Institute, the University of Tokyo, for allowing us to use their waveform data. We are very grateful to the reviewers for their useful comments regarding our manuscript. This study was partly supported by the Special Coordination Funds for the Promotion of Science and Technology offered by the Ministry of Education, Culture, Sports, Science and Technology of Japan, (MEXT), titled as the integrated research on the IwateMiyagi Nairiku Earthquake in 2008.

\section{References}

Abe, S., H. Saito, H. Sato, S. Koshiya, K. Shiraishi, F. Murakami, N. Kato, T. Kawanaka, and T. Kuroda, Integrated seismic imaging of active and passive data for the delineation of active faults and crustal structure in the Kitakami Lowland, Northeast Japan, Proceedings of the118th SEGJ Conference, 124-126, 2008.

Active Fault Research Group, Active Faults in Japan: Sheet Maps and Inventories (revised edition), 437 pp., University of Tokyo Press, Tokyo, 1991 (in Japanese).

Hikima, K., S. Miyazaki, and K. Koketsu, Rupture process of the 2008 Iwate-Miyagi Nairiku earthquake $\left(M_{\mathrm{j}} 7.2\right)$, Japan, inferred from strong motion and geodetic data, Eos Trans. AGU, 89, Fall Meet. Suppl., Abstract S51D-1789, 2008

Japan Meteorological Agency, Outline of the Iwate-Miyagi Nairiku earthquake in 2008, Programme and abstracts, The $7^{\text {th }}$ General Assembly of Asian Seismological Commission and the 2008 Fall meeting of Seismological Society of Japan, A11-01, 2008.

Kato, A., T. Miyatake, and N. Hirata, Asperity and barriers of the 2004 mid-Niigata Prefecture earthquake revealed by highly dense seismic observations, Bull. Seismol. Soc. Am., 100, 298-306, 2010.

Kato, N., H. Sato, and N. Umino, Fault reactivation and active tectonics on the fore-arc side of the back-arc rift system, NE Japan, J. Struct. Geol., 28, 2011-2022, 2006.

Kissling, E., Geotomography with local earthquake data, J. Geophys. Res., 93, 1073-1085, 1988.

Kissling, E., W. L. Ellsworth, D. Eberhart-Phillips, and U. Kradolfer, Initial reference models in local earthquake tomography, J. Geophys. Res., 99, 19635-19646, 1994.

Kitamura, N., Geological Map of Japan 1:50,000, Yakeishi-dake, 48 pp., Geological Survey of Japan, Tsukuba, Japan, 1965.

Kurashimo, E., N. Hirata, Y. Morita, and N. Yuki, A dense seismic observation system with small high-performance off-line data loggers, Zisin, 59, 107-116, 2006 (in Japanese with English abstract).

Kurashimo, E., H. Sato, S. Abe, T. Iwasaki, T. Iidaka, N. Kato, M. Saka,
S. Koshiya, M. Noda, M. Serizawa, F. Sato, F. Watahiki, T. Mogi, R. Hanada, T. Kawanaka, S. Sakai, A. Kato, T. Kanazawa, and N. Hirata, A high-density seismic array observation across northern focal area of the 2008 Iwate-Miyagi Nairiku earthquake, Bull. Earthq. Res. Inst., Univ. Tokyo, 2011 (in press).

Ohta, Y., M. Ohzono, S. Miura, T. Iinuma, K. Tachibana, K. Takatsuka, K. Miyao, T. Sato, and N. Umino, Coseismic fault model of the 2008 IwateMiyagi Nairiku earthquake deduced by a dense GPS network, Earth Planets Space, 60(12), 1197-1201, 2008.

Okada, T., A. Hasegawa, J. Suganomata, N. Umino, H. Zhang, and C. $\mathrm{H}$. Thurber, Imaging the heterogeneous source area of the 2003 M6.4 northern Miyagi earthquake, NE Japan, by double-difference tomography, Tectonophysics, 430, 67-81, 2007.

Okada, T., N. Umino, A. Hasegawa, and the Group for the aftershock observations of the Iwate-Miyagi Nairiku Earthquake in 2008, The IwateMiyagi Nairiku Earthquake in 2008, Kagaku, 78, 978-984, 2008 (in Japanese).

Ozawa, A., T. Hiroshima, M. Kamazawa, and Y. Suda, Geological Map of Japan 1:200,000, Shinjo and Sakata, Geological Survey of Japan, Tsukuba, Japan, 1988.

Saito, H., S. Abe, K. Shiraishi, H. Sato, S. Koshiya, N. Kato, and T. Kawanaka, Deep seismic reflection profiling across the Kitakami Lowland, Northeast Japan, Proceedings of the 118th SEGJ Conference, 127 130, 2008.

Sato, H., The relationship between late Cenozoic tectonic events and stress field and basin development in northeast Japan, J. Geophys. Res., 99, 22261-22274, 1994.

Tajikara, M. and Y. Ikeda, Vertical crustal movement and development of basin and range topography in the middle part of the Northeast Japan arc estimated from fluvial/marine terrace data, Daiyonki-kenkyu, 44(4), 229-245, 2005 (in Japanese with English abstract).

Tajikara, M., Y. Ikeda, and T. Nohara, Source fault of the Iwate-Miyagi Nairiku earthquake in 2008 estimated by distribution of heights of fluvial terraces, Zisin, 62, 1-11, 2009 (in Japanese with English abstract).

Takada, Y., T. Kobayashi, M. Furuya, and M. Murakami, Coseismic displacement due to the 2008 Iwate-Miyagi Nairiku earthquake detected by ALOS/PALSAR: preliminary results, Earth Planets Space, 61, e9-e12, 2009.

Takeuchi, M., K. Kano, M. Ujiie-Mikoshiba, M. Nakagawa, and M. Komazawa, Geological Map of Japan 1:200,000, Ichinoseki, Geological Survey of Japan, AIST, Tsukuba, Japan, 2005.

Thurber, C. and D. Eberhart-Phillips, Local earthquake tomography with flexible gridding, Comp. Geosci., 25, 809-818, 1999.

Yokota, Y., K. Koketsu, K. Hikima, and S. Miyazaki, Ability of 1-Hz GPS data to infer the source process of a medium-sized earthquake: The case of the 2008 Iwate-Miyagi Nairiku, Japan, earthquake, Geophys. Res. Lett., 36, L12301, doi:10.1029/2009GL037799, 2009.

E. Kurashimo (e-mail: ekura@eri.u-tokyo.ac.jp), H. Sato, S. Abe, T. Iwasaki, T. Iidaka, N. Kato, S. Koshiya, T. Kawanaka, and N. Hirata 